International Journal of Instruction e-ISSN: 1308-1470 • www.e-iji.net

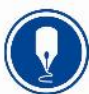

October $2018 \bullet$ Vol.11, No.4

p-ISSN: 1694-609X

pp. 527-544

Received: 05/05/2018

Revision: 26/06/2018

Accepted: 30/06/2018

\title{
The Effect of Task-Based Language Teaching Instruction on the Iranian Intermediate EFL Learners' Writing Performance
}

\author{
Ali Derakhshan \\ Asst. Prof. in Applied Linguistics, English Language and Literature Department, \\ Golestan University, Gorgan, Iran, a.derakhshan@gu.ac.ir
}

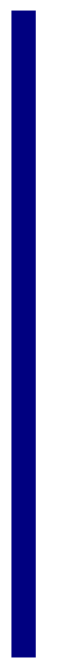

The present study sought to investigate the effects of Summary Writing (SW), Picture Writing (PW), and Topic Writing (TW) tasks on the accuracy and complexity of Iranian intermediate EFL learners' writing performance. To this end, of 61 students majoring English Literature in Golestan University, Gorgan, Iran, 43 (10 males, 33 females) of them were considered homogenous as intermediate learners. The participants were then randomly divided into three groups of SW, $\mathrm{PW}$, and TW receiving six 60-minute sessions of instruction covering five units of "Improve Your IELTS Writing Skills" (McCarter \& Whitby, 2014). With respect to the accuracy of writing productions, the results revealed that intervention was effective and reached the significance level, and the results of post hoc test illustrated that SW outperformed both TW and PW and that TW had a better performance than PW. Regarding the complexity of writing products, it was revealed that instruction was effective and statistically significant. The results of post hoc test demonstrated that SW had the best performance compared to PW and TW although no difference was found between PW and TW. Subsequently, the paper discusses implications for learners and teachers and suggests some avenues for further research.

Keywords: task-based language teaching, picture writing, summary writing, topic writing, EFL

\section{INTRODUCTION}

Due to the fact that English is one of the most dominant languages worldwide, there is widespread interest for good communication skills in English worldwide (Tavakoli, Bahrami, \& Amirian, 2012). While English is accepted as the language for the international communication and globalization, it is the written English that is one of the dominant media for much of this communication primarily since Internet is the most influential communication tool and most of the communication through the Internet is written (Kroll, 2003). Birjandi and Malmir (2009) mention that "Being an internationally recognized language, most publications as well as website materials use

Citation: Derakhshan, A. (2018). The Effect of Task-Based Language Teaching Instruction on the Iranian Intermediate EFL Learners' Writing Performance. International Journal of Instruction, 11(4), 527-544. https://doi.org/10.12973/iji.2018.11433a 
English as their means of communication." He also annotates that "In Iran, like in many other countries, there is a strong tendency toward developing writing ability in a foreign language, namely English" (p. 2), which buttress the idea that writing well is not just an option for students today but a necessity. In effect, it can be proclaimed that writing now becomes much more important in the second language curriculum than heretofore and regarded as an influential skill that can impact students' lives (Birjandi\& Malmir, 2009; Kroll, 2003).

In spite of this significance, reviewing the literature, one can realize that academic writing has received scant attention in English language teaching worldwide. For instance, Richards (1990) states that "the nature and significance of writing have traditionally been underestimated in language teaching" (p. 106). Alternatively, Marashi and Dadari (2012) propound that in Iran's universities, writing receives little consideration in language learning classes although its significance for academic work in higher education is highly apprciated by educational authorities. Quite on par with the above concerns, Richards and Renandya (2002) state that there is no doubt that writing seems to be the most difficult skill for second language learners to master. The difficulty pertains not only to generating and organizing ideas but also to translating those ideas into readable text.

To ameliorate this unfavorable situation, so many researchers agree that replacing taskbased language teaching (TBLT) method in place of traditional presentation, practice, and production (PPP) method of teaching makes writing classes more enjoyable, authentic, and communicative (Dobao, 2012; Ellis, 2008; Robinson, 2005; Skehan, 1998). In this line, Carless (2009) claims that " TBLT brings about more successful language learning on the part of the learners by actively involving them in doing tasks which indeed result in their higher levels of motivation" (p. 56). Besides, the results of the study conducted by Sinaga and Feranie (2017) manifested that the embedding of non-traditional writing tasks within the course of modern physics led to the improvement of critical thinking skills and writing quality among students of Physics Education.

Furthermore, it is generally assumed that researchers conceptualize writing performance in terms of complexity, accuracy, and fluency (Frear \& Bitchener, 2015; Johnson, 2017). Thus, in TBLT classes, the impact of tasks is generally measured by examining changes in fluency, accuracy, and complexity. To explicate the idea, Pourdana, Karimi Behbahani, and Safdari (2011) highlight that TBLT as a remedial procedure provides intermediate Iranian EFL learners with better performance in the accuracy and complexity in their writings, helps them express themselves better in English, and also overcome their weaknesses in written production. Additionally, some studies have been conducted on the effect of task repetition on accuracy and complexity (Birjandi \& Ahangari, 2008), on the planning and task types (Ellis \& Yuan, 2004; Foster \& Skehan, 1996, 1999), on the task structure and processing conditions (Skehan \& Foster, 1999), on the writing tasks and collaboration (Storch \& Wigglesworth, 2007), and on the cooperative learning and critical thinking (Khabiri \& Firooz, 2013). Other studies have investigated the influence of collaborative writing tasks on the jointly written text 
quality (Storch, 2005), and on the text accuracy, complexity, and fluency, as well as the nature of interaction occurring among students throughout the writing process (Dobao, 2012). Further studies have examined the impact of cognitive task complexity on writing complexity (Frear \& Bitchener, 2015). And finally, some other researchers have investigated the influence of multiple wiki writing tasks on changes in interaction patterns (Li \& Kim, 2016), the impact of dialogic interactions and feedback on writing performance (Merkel, 2018), and the influence of different writing tasks on writing performance (Abdali \& Fatemipour, 2014). However, very few studies have been conducted on the effects of Picture Writing (PW), Summary Writing (SW), and Topic Writing (TW) on Iranian intermediate EFL learners' writing performance.

Consequently, the present study made an attempt to investigate the impact of these three task type instructions on two aspects of L2 writing proficiency, i.e., accuracy and complexity which were proposed by Skehan (1998) and Skehan and Foster (2001) as different dimensions of production.

\section{REVIEW OF THE RELATED LITERATURE}

The prolific literature on task-based approaches to language teaching has represented its emergence and popularity since the last two decades. Considering this notion, Johnson (2001) notes that "it is possible that the late 1990s will be known in applied linguistics as The Age of the Task" (p. 195). Besides, Malmir, Najafi Sarem, and Ghasemi (2011) claim that "nowadays the concept of task and task-based methodology have been the common orthodoxy in the field of language teaching and it is getting more and more importance in ELT" (p. 81).

According to Richards and Schmidt (2002), "task-based language teaching is an extension of the principles of communicative language teaching (CLT) and an attempt by its proponents to apply principles of second language learning to teaching" (p. 585). In line with them, Richards and Rodgers (2001) believe that "TBLT is a logical development of CLT" (p. 223). Basically, the substitution of CLT by the paradigms of TBLT can be regarded as a change of focus rather than a revolution in ELT. Nevertheless, we should consider that this concern for task as a main guiding pedagogical principle, grew out of dissatisfaction with the ways in which mainstream CLT appeared to be developing, and in particular with CLT's apparent inability to come up with modern issues relating to the content of language learning.

Skehan defines task as an activity in which: "meaning is primary; there is some communication problem to solve; there is some sort of relationship to comparable realworld activities; task completion has some priority; the assessment of the task is in terms of outcome" (as cited in Samuda \& Bygate, 2008, p. 63). This definition emphasizes the use of real-world tasks that are comparable to authentic task behavior. Furthermore, it proposes that task performance often involves achieving a goal or arriving at an outcome. Similarly, Nunan (2004) mentions that "the use of authentic input is a central characteristic of task-based language teaching" (p. 174). Additionally, Bagheri, Rahimi, and Riasati (2012) claim that tasks help learners to communicate with each other in real time. Because of the immediate pressures of spontaneous communication in tasks, 
learners need to simultaneously concentrate on both form and meaning. To these researchers, tasks improve forms of second language learners' writing together with meaning.

According to Richards and Rodgers (2001), "tasks are believed to foster a process of negotiation, modification, rephrasing and experimentation that are at the heart of second language learning" (p. 228). Therefore, effective learning in TBLT occurs when students are fully engaged in a language task, rather than just learning about language. To Nunan (2004), "the concept of task has become an important element in syllabus design, classroom teaching and learner assessment. It underpins several significant research agendas, and it has influenced educational policymaking in both ESL and EFL settings" (p. 1). Tasks create an interactive classroom where the students are learning to convey their meaning in a second language. Bereiter and Scardamalia reason how "a task is used to create some challenge aimed at promoting language development" (as cited in Samuda \& Bygate, 2008, p. 67). For other researchers as Cheng-jun (2006), task-based approach provides opportunities for the learners "to experiment with and explore both spoken and written language through learning activities which are designed to engage learners in the authentic, practical and functional use of language for meaningful purposes, to cultivate the learners' communicative competence" (p. 6).

To name but a few, the first relevant experimental study in this realm was performed by Chen and $\mathrm{Wu}$ (1998) who conducted this project to decide whether planning and task types have any significant effect on writing performance of 42 EFL university students. The planning variable was halved into Time Constrained and Time Unconstrained. Also, the task-type variables were Recall Writing (RW), Topic Writing (TW), and Summary Writing (SW). They devised the study so that they could investigate the impact of these writing tasks on fluency, complexity, and accuracy of writing performance of EFL learners. For the effects of planning, they concluded that no significant differences were found in any of the three types of tasks, but for accuracy, the time-unconstrained group outperformed the time-constrained group in SW whereas no differences were found in the other two types of writing tasks. For the effects of task types, they promulgated that in the time-constrained situation, learners did better in SW than in TW. In the timeunconstrained situation, learners did better in SW than in the other two types of writing. Furthermore, they expressed that in the time-constrained situation, learners outperformed in TW than in the other two types of tasks. Additionally, they stated that no significant differences were found in the time-unconstrained situation. They also claimed that SW was a more cognitively demanding task than Recall-Writing. Moreover, they mentioned that familiarity of the topic of tasks was an important issue which must be considered while surveying the impact of any kind of task-based approach on EFL learners writing performance.

Another study was conducted by Chen and $\mathrm{Wu}$ (2001) to investigate the effects of four different writing tasks, i.e., TW, PW, SW, and Graphic Writing (GW) on the writing performance of 56 EFL learners. On the whole, the results of the study demonstrated the significant effect of TBLT on complexity, accuracy and fluency of EFL learners' writing performance. Moreover, these results represent that for the impact of task types on 
fluency, 1) there was not any significant difference between SW, TW, and PW; and 2) TW produced significantly longer texts than GW and SW. After measuring the impact of task types on complexity, the results manifested that for lower advanced level group: $\mathrm{SW}>\mathrm{TW} / \mathrm{PW}>\mathrm{GW}$; and for advanced level group: GW / SW > TW / PW. Besides, for the impact of task types on accuracy, the results revealed that for lower advanced level group: $\mathrm{SW}>\mathrm{PW}>\mathrm{TW}>\mathrm{GW}$; and for advanced level group: TW / GW $>$ PW / SW. This study further portrays that L2 writing is special in that linguistic problem may affect not only the linguistic formulating process, but also the whole writing process.

In sum, the abovementioned studies have been conducted to investigate the impact of different kinds of tasks on oral performance of EFL learners. However, to the researcher's best knowledge very few studies have examined the impact of TBLT on EFL learners' writing performance. Thus, this study, being enlightened by Chen and Wu's (2001) study, aimed to investigate the impact of three different pedagogic task types, i.e., TW, SW, and PW on complexity and accuracy of Iranian intermediate EFL learners' writing performance. In retrospect, the present study attempts to seek the following research questions:

1. Do types of writing tasks, TW, SW, and PW, have any significant effect on the accuracy of Iranian intermediate EFL learners' writing performance?

2. Do types of writing tasks, TW, SW, and PW, have any significant effect on the complexity of Iranian intermediate EFL learners' writing performance?

\section{METHOD}

\section{Participants}

All English freshman and sophomore students majoring English Literature in Golestan University, Gorgan, Iran were informed to take part in the present study since they had not had any Advanced Writing Course at university. Of the total 61 students, who took Oxford Quick Placement Test as a test of language proficiency to be homogenized, 43 (10 male, 33 female) of them, whose age ranged from 18 to 30 , were considered homogenous as intermediate learners so that they could attend this study. The participants were then randomly divided into three groups including PW, SW, and TW.

\section{Instructional Materials and Instruments}

\section{Instructional Materials}

The main course book used was "Improve Your IELTS Writing Skills" (McCarter \& Whitby, 2014). The purpose of the book is to provide learners with practical guidelines in their writings successfully. The covered topics were Education, Nature, Youth, Health, and the Individual and Society.

\section{Instruments}

\section{Oxford Quick Placement Test}

To homogenize the participants in terms of English language proficiency, Oxford Quick Placement Test (OQPT) developed by Cambridge ESOL and Oxford University Press (2004) validated in 20 countries by more than 6000 students was administered. There 
are two versions of OQPT: a paper and pen $(\mathrm{P} \& \mathrm{P})$ version and a computer-based $(\mathrm{CB})$ version. In this study, $\mathrm{P}$ and $\mathrm{P}$ version consisting of two parts were used. So, the first part, including 40 questions, is taken by candidates at intermediate level. The participants took only the first part due to their proficiency level. According to the guidelines of the test, the students getting a score between 24 and 30 are intermediate, and thus, they could participate in this research. As can be seen in Table 1, the participants were selected based on the ranking of the test. The test ranking is as follows:

Table 1

Oxford Placement Test Scoring Criteria

\begin{tabular}{ll}
\hline Scoring & Proficiency Level \\
\hline $0-15$ & Beginner \\
$16-23$ & Elementary \\
$24-30$ & Intermediate \\
$31-40$ & Advanced \\
\hline
\end{tabular}

Writing Pre-test and Post-test

The second instrument used as the pre-test was to ask students to write an argumentative essay of more than 250 words (See Appendix A). As the final part of this phase, a posttests (See Appendix B) was administered to three classes to examine whether TBLT would have any effect on students' writing performance and also which writing task leads to superior results in writing performance of these intermediate EFL learners. To control the degree of difficulty of the writing tasks, the genre of the pre-test and post-test was the same; both of them were of argumentative nature.

\section{Procedure}

\section{Task}

The three groups received six 60-minute sessions of instruction twice a week. Every session they were taught based on the interventions explicated below. The participants wrote one argumentative essay, the topics of which were selected from (McCarter \& Whitby, 2014), and they were given feedback similarly.

\section{Task Conditions}

\section{Topic Writing (TW)}

The participants in this group consisted of 15 (4 male and 11 female) intermediate EFL learners. TW requires learners to retrieve knowledge from their long-term memory and put them on the paper as a measurable content to represent someone's proficiency in the target language (Chen \& Wu, 2001). To achieve this end, learners had to formulate newly generated ideas in a foreign language simultaneously and spontaneously. The learners had to write one essay for each session. In topic writing tasks, "students are provided with an opportunity to present their ability to organize their ideas for communication" (Chen \& Wu, 2001, p.18). 


\section{Picture Writing $(P W)$}

The participants in this group were 14 (4 male and 10 female) intermediate EFL learners. Chen and Wu (2001) argue that "a picture is worth a thousand words" (p. 18). For the PW task, students had to construct an essay from a set of pictures. Therefore, in this writing task, the participants were required to write a story based on a set of pictures. This task involved encoding new, visual information into linguistic form and required some degree of imagination. Thus, participants were required to look at a series of pictures and inscribe based on the prompts, and accordingly write an essay about them. The students wrote one essay each session.

\section{Summary Writing (SW)}

The participants in this group were 14 (3 male and 11 female) intermediate EFL learners. SW tasks, according to Chen and Wu (2001), require learners to activate their schemata and simultaneously utilize their active pre-existing schemas to varying degrees. After the learners read the text, they are supposed to recreate it in their own words. The underlying assumption is that in processing a text for meaning, learners have to store the propositional content but not the linguistic forms to encode the content. The students in this group were required to reconstruct the text; therefore, they were asked to draw on their own linguistic resources.

\section{Task Measures}

Accuracy

Samuda and Bygate (2008) measured the accuracy of writings of EFL learners by counting: 1. Error-free clauses: the proportion of clauses that did not contain any error. All errors relating to syntax, morphology and lexical choice were considered. The accuracy was measured through counting the frequency of errors per T-unit, the higher the number, the less accurate the written text accuracy would be. Moreover, accuracy has been measured by the percentage of error-free $S$-nodes. This percentage has been obtained by dividing the error-free S-nodes by the total number of S-nodes. Error free Snodes refer to $\mathrm{S}$-nodes in which no error was seen with regard to syntax, morphology, lexical choice or word order. However, in this study accuracy was measured by dividing the percentage of error-free clauses by the total number of clauses.

\section{Complexity}

Skehan (1996) defines complexity as "the elaboration or ambition of the language that is produced" (p. 22). For Skehan, complexity is measured by dividing the total number of clauses by the total number of C-units produced by each subject (as cited in Nunan, 2004, p. 87). Samuda and Bygate (2008) prescribed the following necessitated criteria as the agenda for counting the complexity of writing performance of EFL learners:

a. The number of clauses per T-unit. A T-unit is a measure of the linguistic complexity of sentences. It is defined as "consisting of one independent clause together with whatever dependent clauses are attached to it" (Richards, Platt, \& Weber, 1985, p. 390). 
The T-unit analysis was initially developed to assess written language and has been replaced by the c-unit analysis for oral language.

b. The number of words per T-unit has been employed as a measure of language complexity in writing. (pp. 151-152).

\section{Inter-rater Reliability between the Two Raters}

To determine if there was an acceptable level of inter-rater reliability, all the writing tests were checked by two raters. A Pearson product-moment correlation coefficient was computed to assess the inter-rater reliability between the two raters. Table 2 illustrates that there is a positive correlation between the two raters in the pre-test $(r=.8, n=43, p$ $=.000, \alpha=.01)$ and post-test $(r=.87, n=43, p=.000, \alpha=.001)$.

Table 2

The Correlation between the Two Raters in the Pre-test and Post-test

\begin{tabular}{llllll}
\hline & & PostR1 & PostR2 & PretestR1 & PretestR2 \\
\hline PostR1 & Pearson Correlation & 1 & $.87^{* *}$ & $.75^{*}$ & $.74^{* *}$ \\
& Sig. (2-tailed) & & .000 & .000 & .000 \\
& $\mathrm{~N}$ & 43 & 43 & 43 & 43 \\
PostR2 & Pearson Correlation & $.87^{* *}$ & 1 & $.73^{* *}$ & $.78^{* *}$ \\
& Sig. (2-tailed) & .000 & & .000 & .000 \\
& $\mathrm{~N}$ & 43 & 43 & 43 & 43 \\
\hline
\end{tabular}

**. Correlation is significant at the 0.01 level (2-tailed).

\section{FINDINGS}

\section{Research Question One}

To understand whether the three groups enjoyed the same level of homogeneity with regard to their writing accuracy, one-way ANOVA was run to compare the means of the TW, PW, and SW groups prior to the main study. Table 3 illustrates the descriptive statistics for the groups. As can be seen, there is no significant difference in the mean scores across the three groups. PW $(M=12.24, S D=1.61)$, TW $(M=12.8, S D=1.58)$, and $\mathrm{SW}(M=12.41, S D=1.51)$. The comparison of the mean scores of the three groups indicates that the groups were very close in terms of their writing proficiency before the intervention.

Table 3

Descriptive Statistics Pre-test of Writing Accuracy by Groups

\begin{tabular}{|c|c|c|c|c|}
\hline & $\mathrm{N}$ & Mean & Std. Deviation & Std. Error \\
\hline Picture Writing & 14 & 13.33 & 1.614 & .212 \\
\hline Topic Writing & 15 & 14.17 & 1.582 & .345 \\
\hline Summary Writing & 14 & 14.42 & 1.513 & .205 \\
\hline Total & 43 & 13.97 & 1.574 & .143 \\
\hline
\end{tabular}

*Note: The scores are out of 20.

Based on the results displayed in Table $4(F(2,40)=.14, \rho=.64)$, it can be concluded that there were not any significant differences between means of the three groups on the 
pre-test of writing accuracy. Thus, it can be claimed that they enjoyed the same level of writing accuracy prior to the main study.

Table 4

One-Way ANOVA in the Pre-test of Accuracy

\begin{tabular}{lccccc}
\hline & Sum of Squares & Df & Mean Square & F & Sig. \\
\hline Between Groups & 7.432 & 2 & 2.456 & .140 & .643 \\
Within Groups & 731.250 & 40 & 21.523 & & \\
Total & 738.682 & 42 & & & \\
\hline
\end{tabular}

To find out the effect of intervention on the three groups, the descriptive statistics are displayed in Table 5.

Table 5

Descriptive Statistics Post-test of Writing Accuracy

\begin{tabular}{lcccc}
\hline & $\mathrm{N}$ & Mean & \multicolumn{1}{c}{ Std. } & Std. Deviation \\
\hline Picture Writing & 14 & 15.45 & 1.262 & .98 \\
Topic Writing & 15 & 16.89 & 1.492 & 1.323 \\
Summary Writing & 14 & 18.12 & 1.301 & 1.292 \\
Total & 43 & 16.82 & 1.491 & .792 \\
\hline
\end{tabular}

As can be seen in Table $6,(F(2,42)=4.29, \rho=.000<.05)$, it can be concluded that there were significant differences between means of the three groups on the post-test of writing accuracy because the amount of variability between groups is different from the amount of variability within groups. Thus, it can be concluded that the types of writing tasks have significant effects on accuracy of Iranian intermediate EFL learners' writing performance.

Table 6

One-Way ANOVA Post-test of Writing Accuracy by Groups

\begin{tabular}{llllll}
\hline & Sum of Squares & Df & Mean Square & F & Sig. \\
\hline Between groups & 23.025 & 2 & 6.273 & 4.290 & .000 \\
Within Groups & 134.563 & 40 & 1.357 & & \\
Total & 157.588 & 42 & & & \\
\hline
\end{tabular}

However, one-way ANOVA does not tell us the differences between the groups; to see where the differences exactly lie, a Scheffe test was run. According to Table 7, there is a significant difference between the PW $(M=15.45)$ and SW $(M=18.12)$ groups on the post-test of writing accuracy $(M D=2.67, p=.000<.05)$. Moreover, there is a significant difference between PW $(\mathrm{M}=15.45)$ and TW $(M=16.89)$ groups on the post-test of writing accuracy $(M D=1.44, p=.002>.05)$. Furthermore, there is a significant difference between the SW $(M=18.12)$ and TW $(M=15.45)$ groups on the post-test of writing accuracy $(M D=1.23, p=.007)$. Thus, based on the findings, it is concluded that there are some meaningful differences across the groups. In the nutshell, it is shown that SW outperformed PW and TW, and TW had a better performance than PW. 
Table 7

Post-Hoc Scheffe Tests for Writing Accuracy across the Three Groups

\begin{tabular}{lllcl}
\hline \multicolumn{1}{c}{ (I)Group } & \multicolumn{1}{c}{$(\mathrm{J})$ Group } & Mean Difference (I-J) & Std. Error & Sig. \\
\hline Picture & Summary Writing & $-2.67^{*}$ & 2.27 & .000 \\
Writing & Topic Writing & $-1.44^{*}$ & 2.32 & .002 \\
Topic & Summary Writing & $-1.23^{*}$ & 2.27 & .007 \\
Writing & Picture Writing & $1.44^{*}$ & 2.32 & .002 \\
Summary & Picture Writing & $2.67^{*}$ & 2.32 & .000 \\
Writing & Topic Writing & $1.23^{*}$ & 2.32 & .007 \\
\hline
\end{tabular}

*. The mean difference is significant at the 0.05 level.

\section{Research Question Two}

Table 8 indicates the descriptive statistics of the three groups after the treatment. Accordingly, it indicates that in the pre-test the groups approximately had the same mean scores. In the post-test, the mean score of the three groups underwent some changes which per se means that different writing tasks have had different effects. It is observed that the mean score $(M=16.12)$ of the SW is larger than other groups which is followed by the TW. To see whether the difference in the pre-test and post-test is significant, a one-way ANOVA was run.

Table 8

The Descriptive Statistics for the Pre-test and Post-test of Complexity

\begin{tabular}{|c|c|c|c|c|c|}
\hline \multirow{2}{*}{ Pre-test } & & $\mathrm{N}$ & Mean & Std. Deviation & Std. Error \\
\hline & & & & & .51 \\
\hline \multirow{7}{*}{ Post-test } & Topic Writing & 15 & 11.90 & .94 & .28 \\
\hline & Picture Writing & 14 & 11.45 & 1.29 & .35 \\
\hline & Total & 43 & 11.79 & 1.89 & .31 \\
\hline & Summary Writing & 14 & 16.12 & 2.04 & .34 \\
\hline & Topic Writing & 15 & 14.40 & 1.43 & .51 \\
\hline & Picture Writing & 14 & 13.87 & 2.38 & .64 \\
\hline & Total & 43 & 14.79 & 1.74 & .38 \\
\hline
\end{tabular}

The effect of the three kinds of tasks on the Iranian intermediate EFL learners' writing ability was measured by analyzing learners' writing ability in the post-test. To do so, the three groups were simultaneously compared to see if there were any meaningful differences among them. Therefore, one-way ANOVA was applied. The results indicate that in the pre-test, the groups were homogeneous since $p=561>.05$. As seen in Table 9 , the amount of variability between groups in the post-test (SS between groups $=61.27$ ) is different from the amount of variability within the groups (SS within groups= 58.30), which indicates that there are some differences in the groups. Moreover, the $F$ ratio (with three degrees of freedom) is larger than the observed value of $F$. $F(2,40)=14.45$, $p=.000,<.05$, which means that significant group differences were observed with regard to performance of the three groups. 
Table 9

The Results of One-way ANOVA for Complexity in the Pre-test and Post-test

\begin{tabular}{|c|c|c|c|c|c|c|}
\hline & & Sum of Squares & $\mathrm{df}$ & Mean Square & $\mathrm{F}$ & Sig. \\
\hline \multirow[t]{3}{*}{ Pre-test } & Between Groups & 1.25 & 2 & .47 & .33 & .561 \\
\hline & Within Groups & 42.19 & 40 & 1.54 & & \\
\hline & Total & 43.34 & 42 & & & \\
\hline \multirow[t]{3}{*}{ Post-test } & Between Groups & 61.27 & 2 & 27.30 & 14.45 & .000 \\
\hline & Within Groups & 58.30 & 40 & 1.95 & & \\
\hline & Total & 119.57 & 42 & & & \\
\hline
\end{tabular}

The ANOVA table shows that there are meaningful differences, but it does not tell us where the differences exactly are. Thus, to understand exactly where the differences lie, a post hoc test of Scheffe was run. According to Table 10, there was not any significant difference between TW $(M=14.4)$ and PW $(M=13.87)$ groups on the post-test of writing complexity $(M D=.53, p=.23)$. Furthermore, it was found that there was a significant difference between the SW $(M=16.12)$ and TW $(M=14.40)$ groups on the post-test of writing complexity $(M D=1.72, p=.002)$. Moreover, there was a significant difference between the SW $(M=16.12)$ and PW $(M=13.87)$ groups on the post-test of writing complexity $(M D=2.25, p=.000)$. In a nutshell, it is concluded that $\mathrm{SW}$ outperformed both PW and TW while no difference was found between TW and PW although TW had a better performance than PW.

Table 10

Post-Hoc Scheffe Tests for Writing Complexity across the Groups

\begin{tabular}{|c|c|c|c|c|c|c|c|}
\hline \multirow[b]{2}{*}{$\begin{array}{l}\text { Dependent } \\
\text { Variable }\end{array}$} & \multirow[b]{2}{*}{ (I) Treatment } & \multirow[b]{2}{*}{$(\mathrm{J})$ Treatment } & \multirow{2}{*}{$\begin{array}{c}\text { Mean } \\
\text { Difference (I- } \\
\text { J) }\end{array}$} & \multirow[b]{2}{*}{$\begin{array}{l}\text { Std. } \\
\text { Error }\end{array}$} & \multirow[b]{2}{*}{ Sig. } & \multicolumn{2}{|c|}{$95 \%$ Confidence Interval } \\
\hline & & & & & & $\begin{array}{l}\text { Lower } \\
\text { Bound }\end{array}$ & Upper Bound \\
\hline \multirow[t]{6}{*}{ Post-test } & Summary & Topic Writing & $1.72 *$ & .58 & .028 & -.80 & 2.07 \\
\hline & & Picture Writing & $2.25 *$ & .58 & .000 & 1.65 & 4.53 \\
\hline & Topic Writing & Picture Writing & .53 & .58 & .231 & 1.01 & 3.89 \\
\hline & & $\begin{array}{l}\text { Summary } \\
\text { Writing }\end{array}$ & $-1.72 *$ & .58 & .028 & -2.07 & .80 \\
\hline & Picture Writing & $\begin{array}{l}\text { Summary } \\
\text { Writing }\end{array}$ & $-2.25 *$ & .58 & .000 & -4.53 & -1.65 \\
\hline & & Topic Writing & -.53 & .58 & .231 & -3.89 & -1.01 \\
\hline
\end{tabular}

*. The mean difference is significant at the 0.05 level.

\section{DISCUSSION}

Reviewing the promulgated findings of this study demonstrates that task-oriented practices lead to better performance of EFL learners in comparison with conventional approaches to teaching writing due to involvement nature of task-based practices (Ellis, 2004; Foster \& Skehan, 1996; Nunan, 2004; Skehan \& Foster, 2001). In conventional practices of teaching writing, one notes that teachers only oblige the students to write based on a prescribed topic. In such conventional writing classes, students must develop the topic and support it without any thought-provoking procedure. There is no 
interaction between students and teachers in such writing classes whereas in task-based classes, students are supplied with real-life situations when they want to put their thought on paper. These bright results of task-based writing introduce the paradigm of this approach as a facilitative approach to teach writing. The findings of the present study also disclose that all task-based practices lead to better performance of the participants in performing tasks in comparison with pre-test accomplishment. This means that teachers utilizing task-based practices can improve the present condition of intermediate EFL learners' writing performance. Consequently, some tasks are more fruitful than others.

As to the accuracy of writing productions, it is concluded that SW outperformed both PW and TW; besides, TW outperformed PW concerning writing accuracy. Moreover, with regards to the complexity of written production, it is concluded that SW outperformed both PW and TW although no difference was found between TW and PW regarding writing complexity.

Writers in academic settings are usually obliged to write academic essays for assessing complexity, accuracy and fluency of their writings. The five-paragraph essay is usually regarded as the classic format for academic writings. Teachers in academic settings usually persuade their students to write based on the norms of this paradigm. The nature and significance of writing have often been underscored in language teaching; however, some language learners may take writing into account as the most difficult skill among the four macro skills of language to be acquired. Writing practice among four skills is the activity that students practice least outside the class. The fact that most students do not write outside the class indicates that it is impossible for students to develop their competence in English writing. Moreover, teachers usually forget to make their students practice writing which is taken into account as one of important issues among other skills. Nonetheless, it is generally perceived that writing is the most important skill which must be acquired to be utilized for student's success in and out of the classroom. Writing must be considered as an important endeavor methodologically, theoretically and pedagogically.

The researcher also observed that while using task-oriented practices in classes, all students were actively involved in the process of writing and tried to prepare their assignments. In this study, students verbally told the researcher that task-based practices increased the quality of their writings. They further believed that when the teacher altered their styles of teaching, the students felt how these changes improved their writings. Moreover, it is found that task-based practices lead to more interaction in class. The findings of this study are partly attributed to the interactive nature of tasks and the amount of involvement they had. Moreover, regarding TW, these writing tasks are thought to put considerable cognitive demand for idea generation because they required learners to retrieve knowledge from the long-term memory for organizing the content and language into an accurate and complex text. Linguistically, they are also demanding tasks since learners had to formulate newly generated ideas in a foreign language. This interaction was encouraged not individually but collaboratively. The students made use of practice opportunities and brainstorming of their classmates for 
their writings. This interaction in writing classes was a kind of new experience in writing classes that led in turn to an enjoyable classroom atmosphere developed as a result of applying task-based practices in academic settings. This was due to the fact that taskbased approaches usually provide the classes with genuine and enjoyable challenges while students interact with their classmates.

Findings of the present study are consistent with those of Chen and Wu's (1998) and (2001). Concerning complexity, they found that for the lower advanced-level group: SW $>\mathrm{TW} / \mathrm{PW}>\mathrm{GW}$ (Graphic Writing); and for advanced-level group: GW / SW > TW / PW. Also, regarding accuracy, it was found that for lower advanced-group SW $>$ PW $>\mathrm{TW}>\mathrm{GW}$; and for advanced-level group: TW / GW > PW / SW. In other words, their results and those of the present study confirmed the claim that various writing tasks of different cognitive demand impact writing performance differently. Moreover, the present study also supports the results of Pourdana et al.'s (2010) study. Their findings showed a high degree of accuracy and complexity in EFL learners' performance on TW task, comparing to aspect of fluency which was shown to be the highest in EFL learners' performance on Picture Description task. Alternatively, Abdali and Fatemipour (2014) reported the superiority of SW group for complexity and Graphic Writing for accuracy of their written productions which support the findings of the present study. Although different kinds of tasks impact on the writing performance of EFL learners differently, students in task-oriented classes welcome this approach.

\section{CONCLUSION AND IMPLICATIONS}

The present study was an endeavor to investigate whether there would be any significant differences between the complexity and accuracy of Iranian intermediate EFL learners' writing across TW, PW, and SW tasks. As to the complexity, results indicate that SW outperformed both PW and TW, but no significant difference was found between PW and TW. Regarding accuracy, it was found that SW outperformed both PW and TW, and TW had a better performance than PW. The findings revealed that applying TBLT approach was helpful in students' writing performance. The results of the study would encourage teachers to exploit various writing tasks for improving EFL learners' writing performance qualitatively and quantitatively. In the light of increasing the mean of students' scores in all three task conditions in relation to the mean of students' scores in pretest, it is suggested that teachers of academic writings make good use of writing tasks for heightening the quality of writing performance of EFL learners.

It can be concluded that TBLT in an intermediate level is educationally effective. Moreover, TBLT enhances students' writing skill and reiterates students' attitudes towards English. Besides, it is proven that the findings of this study provide L2 learners and L2 educators with a clear explanation of how different kinds of writing tasks affect the L2 learners' writings performance which per se demands writing teachers utilize task-based approach to help students be more proficient in writing.

Based on the findings of this study, it is suggested that TBLT appears to be educationally effective for teaching writing in intermediate level academic settings. Additionally, due to the significance of writing instruction and the emergence of new 
practices which have recently arisen, more studies need to be conducted. It is recommended that further experiments be undertaken in the following areas to handle the upcoming challenges. Future longitudinal studies are required to investigate the effect of different writing tasks among other students with different levels of competencies in other academic settings. It is important to note that the majority of previous studies in this area have been conducted in countries other than Iran. It is hoped that more research is done to investigate the impact of different writing tasks on language performance of EFL learners in the context of Iran in the future. The present study has only examined the impact of three tasks from a number of writing tasks on writing performance of intermediate EFL learners. Other studies can investigate the influence of other writing tasks on writing performance of intermediate as well as other levels of EFL learners. The present study focused on the argumentative type of essay writing, so it is also suggested that other studies can explore the effect of different types of tasks on other types of essay writing such as expository, narrative, and descriptive.

\section{REFERENCES}

Abdali, A., \& Fatemipour, H. (2014). The impact of different writing tasks on intermediate EFL learners' writing performance. Theory and Practice in Language Studies, 4(4), 730-735.

Alessi, M. S. and Trollip, R. S. (2001). 3rd Edition Multimedia for Learning-Methods and Development. Needdham Heights, Massahusetts.

Bagheri, M. S., Rahimi, F., \& Riasati, M. J. (2012). Communicative interaction in language learning tasks among EFL learners. Journal of Language Teaching and Research, 3(5), 948-952.

Birjandi, P., \& Ahangari, S. (2008). Effects of task repetition on the fluency, complexity and accuracy of Iranian EFL learners' oral discourse. Asian EFL Journal, 10(3), 28-52.

Birjandi, P. \& Malmir, A. (2009). The effect of task-based approach on the Iranian advanced EFL learners' narrative vs. expository writing. The Iranian EFL Journal, 1(2), $1-26$.

Carless, D. (2009). Revisiting the TBLT versus P-P-P debate: Voices from Hong Kong. Asian Journal of English Language Teaching, 19, 49-66.

Chen, H., \& Wu, X. (1998). The effect of task complexity and task condition on EFL writing performance. Modern Foreign Languages, 80(2), 27-39.

Chen, H., \& Wu, X. (2001). Effect of task type and task condition on EFL writing performance (Unpublished doctoral dissertation). Guangdong University of Foreign Studies: China.

Cheng-jun, W. A. N. G. (2006). Designing communicative tasks for college English courses (Unpublished doctoral dissertation). Yangtze Normal University: China.

Dobao, A. F. (2012). Collaborative writing tasks in the L2 classroom: Comparing group, pair, and individual work. Journal of Second Language Writing, 21(1), 40-58. 
Ellis, R. (2004). Task-based language learning and teaching. Oxford: Oxford University Press.

Ellis, R. (2008). The study of second language acquisition (2nd Ed.). Oxford: Oxford University Press.

Ellis, R., \& Yuan, F. (2004). The effects of planning on fluency, complexity, and accuracy in second language narrative writing. Studies in Second Language Acquisition, 26(01), 59-84.

Foster, P., \& Skehan, P. (1996). The influence of planning and task type on second language performance. Studies in Second Language Acquisition, 18(3), 299-323.

Foster, P., \& Skehan, P. (1999). The influence of source of planning and focus of planning on task-based performance. Language Teaching Research, 3(3), 215-247.

Frear, M. W., \& Bitchener, J. (2015). The effects of cognitive task complexity on writing complexity. Journal of Second Language Writing, 30(1), 45-57.

Johnson, K. (2001). An introduction to foreign language learning and teaching. Longman Pearson Education LTD.

Khabiri, M., \& Firooz, M. (2013). The comparative effect of practicing cooperative learning and critical thinking on EFL learners' writing. Issues in Language Teaching, $1(2), 371-394$.

Kroll, B. (2003). Exploring the dynamics of second language writing. Cambridge: Cambridge University Press.

Li, M., \& Kim, D. (2016). One wiki, two groups: Dynamic interactions across ESL collaborative writing tasks. Journal of Second Language Writing 31(1), 25-42.

Malmir, A., Najafi Sarem, S., \& Ghasemi, A. (2011). The effect of task-based language teaching (TBLT) vs. content-based language teaching (CBLT) on the Iranian intermediate ESP learners' reading comprehension. The Iranian EFL Journal, 7(6), 7994.

Marashi, H., \& Dadari, L. (2012). The impact of using task-based writing on EFL learners' writing performance and creativity. Theory and Practice in Language Studies, 2(12), 2500-2507.

McCarter, S., \& Whitby, N. (2014). Improve your IELTS writing skills. Thailand: Macmillan Publishers Limited.

Merkel, W. (2018). Role reversals: A case study of dialogic interactions and feedback on L2 writing. Journal of Second Language Writing 39(1), 16-28.

Nunan, D. (2004). Task-based language teaching. Cambridge: Cambridge University Press. 
Pourdana, N., Karimi Behbahani, S. M., \& Safdari, M. (2011). The impact of task types on aspects of Iranian EFL learners' writing performance: Accuracy, fluency, and complexity. IPEDR, 20, 261-266.

Richards, J. C. (1990). The language teaching matrix. Cambridge: Cambridge University Press.

Richards, J. C., \& Renandya, W. A. (2002). Methodology in language teaching: An anthropology of current practice. Cambridge: Cambridge University Press.

Richards, J., \& Rodgers, T. (2001). Approaches and methods in language teaching. Cambridge: Cambridge University Press.

Richards, J., \& Schmidt, R. (2002). Longman dictionary of language teaching and applied linguistics. England: Pearson Education Limited.

Richards, J., Platt, J., \& Weber, H. (1985). Longman dictionary of applied linguistics. London: Longman.

Robinson, P. (2005). Cognitive complexity and task sequencing: Studies in a componential framework for second language task design. Annual Review of Applied Linguistics, 43, 1-32.

Samuda, V., \& Bygate, M. (2008). Tasks in second language learning. Great Britain: Antony Rowe Ltd, Chippenham and Eastbourne.

Sinaga, P., \& Feranie, S. (2017). Enhancing critical thinking skills and writing skills through the variation in non-traditional writing task. International Journal of Instruction, 10(2), 69-84.

Skehan, P. (1996). Second language acquisition research and task-based instruction. In J. Willis, \& D. Wilis, (Eds.), challenge and change in language teaching (pp. 17-30). Macmillan: Heinemann.

Skehan, P. (1998). A cognitive approach to language learning. Oxford: Oxford University Press.

Skehan, P., \& Foster, P. (1999). The influence of task structure and processing conditions on narrative retellings. Language Learning, 49(1), 93-120.

Skehan, P., \& Foster, P. (2001).Cognition and tasks. In P. Robinson (Ed.). Cognition and second language instruction (pp. 183-205). Cambridge: Cambridge University Press.

Storch, N. (2005). Collaborative writing: Product, process, and students' reflections. Journal of Second Language Writing 14(3), 153-173.

Storch, N., \& Wigglesworth, G. (2007). Writing tasks: The effects of collaboration. In M. d. P. G. Mayo (Ed.), Investigating tasks in formal language learning (pp. 157-177). London: Multilingual Matters. 
Tavakoli, M., Bahrami, L., \& Amirian, Z. (2012). Improvement of metadiscourse use among Iranian EFL learners through a process-based writing course. Journal of English Language Teaching and Learning, 4(9), 129-164.

\section{Acknowledgments}

The present study was funded by Golestan University, Gorgan, Iran (Grant Number: 95/133/1). The author truly appreciates Golestan University for the financial support, and all the students for their study participation. Besides, my special words of gratitude go to the venerable anonymous reviewers for their valuable comments. 


\section{Appendix A (Pre-test)}

\section{WRITING TASK}

You should spend about 40 minutes on this task.

Write about the following topic:

Universities should spend as much money on library resources as on sports facilities.

\section{To what extent do you agree or disagree with this statement?}

Give reasons for your answer and include any relevant examples from your own knowledge or experience.

Write at least 250 words.

\section{Appendix B (Posttest) \\ WRITING TASK}

You should spend about 40 minutes on this task.

Write about the following topic:

Travelers and business people often come into contact with other cultures briefly. What are the main advantages and disadvantages of doing so?

To what extent do you agree or disagree with this statement?

Give reasons for your answer and include any relevant examples from your own knowledge or experience.

Write at least 250 words. 